\title{
Chapter 18 \\ Radiocesium Concentrations in the Muscle and Eggs of Salmonids from Lake Chuzenji, Japan, After the Fukushima Fallout
}

\author{
Shoichiro Yamamoto, Tetsuya Yokoduka, Ken Fujimoto, Kaori Takagi, \\ and Tsuneo Ono
}

\begin{abstract}
Approximately 18 months (September-December 2012) after the Fukushima Dai-ichi Nuclear Power Plant accident, elevated radiocesium concentrations were detected in muscle and egg samples from masu salmon (Oncorhynchus masou), kokanee (Oncorhynchus nerka), brown trout (Salmo trutta), and lake trout (Salvelinus namaycush) from the Lake Chuzenji system, central Honshu Island, Japan (160 km from the station). Mean muscle concentrations were 142.9-249.2 Bq/ $\mathrm{kg}$-wet, and mean egg concentrations were 38.7-79.0 Bq/kg-wet. No relationship between fork length and muscle radiocesium concentration was observed in any of the species, but significant relationships were found between individual muscle and egg radiocesium concentrations from masu salmon, brown trout, and lake trout.
\end{abstract}

Keywords Brown trout $\bullet$ Kokanee $\bullet$ Lake trout $\bullet$ Masu salmon $\bullet$ Nuclear accident

\footnotetext{
S. Yamamoto $(\bowtie)$

National Research Institute of Aquaculture, Fisheries Research Agency, 2482-3 Chugushi, Nikko, Tochigi 321-1661, Japan

e-mail: ysho@affrc.go.jp

T. Yokoduka

Tochigi Prefectural Fisheries Experimental Station, Sarado, Ohtawara, Tochigi 324-0404, Japan

K. Fujimoto • T. Ono

National Research Institute of Fisheries Sciences, Fisheries Research Agency,

2-12-4, Fukuura, Kanazawa, Yokohama, Kanagawa 236-8648, Japan

K. Takagi

Marine Biological Research Institute of Japan Co., LTD,

4-3-16, Yutaka, Shinagawa, Tokyo 142-0042, Japan

e-mail: takagik@affrc.go.jp 


\subsection{Introduction}

A Japanese governmental agency (Fisheries Agency) and local governments initiated monitoring programs soon after the Fukushima fallout to monitor radioactivity contamination in freshwater and marine fish and invertebrates in the affected areas. The results revealed that radiocesium contamination was transferred quickly to freshwater and marine ecosystems, and elevated radiocesium concentrations were detected in many fish and invertebrates (Fisheries Agency 2012). These concentrations decreased over time in most of the epipelagic fish and neustonic organisms (Buesseler 2012). However, some demersal fish off the coast of Fukushima and some freshwater fish in central and northern Honshu Island continue to exhibit higher radiocesium concentrations (Tateda et al. 2013). Freshwater masu salmon (Oncorhynchus masou) from the Niida River in Fukushima Prefecture contained the highest measured radiocesium concentrations in March 2012 (18,700 Bq/kg-wet weight; Fisheries Agency 2012). Restrictions have been placed on shipping and consumption of 19 commercially important freshwater fish and invertebrate species as of October 2013 in the extensive deposition area of central and northern Honshu Island.

Because of differences in osmoregulatory physiology, radionuclides usually bioaccumulate at higher concentrations in freshwater compared with marine fish. After the Chernobyl nuclear accident (Ukraine), higher radiocesium concentrations persisted in freshwater fish from several European lakes for 10 years and more (Jonsson et al. 1999; Brittain and Gjerseth 2010; Rask et al. 2012). Lake-dwelling freshwater fish in high deposition areas may also sustain long-standing radionuclide contamination, which results from radionuclide recycling within the aquatic environment (Smith and Comans 1996). In this chapter, we describe radiocesium concentrations in muscle and eggs of masu salmon, kokanee, O. nerka; brown trout, Salmo trutta; and lake trout, Salvelinus namaycush, from the Lake Chuzenji system, central Honshu Island, Japan (Fig. 18.1) to understand the effects of radionuclide contamination on salmonid fish. Although Lake Chuzenji is approximately $160 \mathrm{~km}$ from the Fukushima Dai-ichi Nuclear Power Plant (FNPP) in linear distance, the lake watershed area received radiocesium deposits of $8-36 \mathrm{kBq} / \mathrm{m}^{2}$ after the Fukushima accident (Fisheries Research Agency 2012). Salmonid fish support important recreational and commercial fisheries throughout the Japanese Archipelago. Salmonid eggs (usually raw eggs) are also an important food resource for the Japanese. 


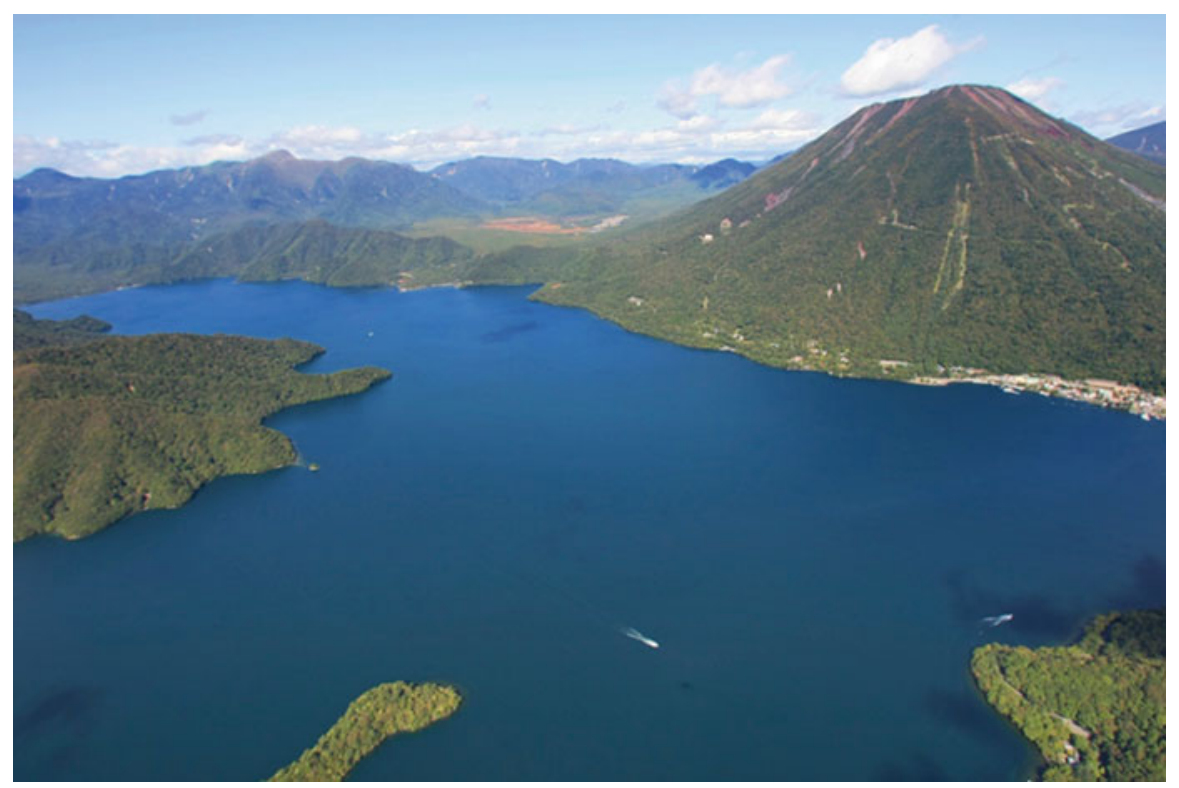

Fig. 18.1 A photograph of Lake Chuzenji

\subsection{Study Area (Lake Chuzenji)}

Lake Chuzenji $\left(36^{\circ} 44^{\prime}\right.$ latitude, $139^{\circ} 27^{\prime}$ longitude) is an oligotrophic, cold-water lake system located in Nikko, Kanto District, Japan (mean surface water quality: $\mathrm{pH}, 8.2$; chemical oxygen demand, $1.4 \mathrm{mg} / \mathrm{l}$; total phosphorus, $0.004 \mathrm{mg} / \mathrm{l}$; total nitrogen, $0.26 \mu \mathrm{g} / \mathrm{l}$; chlorophyll $a, 2.4 \mu \mathrm{g} / \mathrm{l}$ ) (Tochigi Prefecture Japan 2012). At $1,269 \mathrm{~m}$ above sea level, it is the highest major natural lake in Japan. It is approximately $11.5 \mathrm{~km}^{2}$ in surface area and $163 \mathrm{~m}$ in maximum depth (Yokoyama and Yamamoto 2012). The water turnover rate is about 6 years. No fish originally inhabited Lake Chuzenji. However, many freshwater fish, mostly salmonids, have been introduced repeatedly since 1873 . The lake system is currently inhabited by four exotic salmonids, namely brook trout, Salvelinus fontinalis; lake trout, brown trout, rainbow trout, $O$. mykiss; and three native Japanese salmonids, white-spotted charr, Salvelinus leucomaenis; masu salmon, and kokanee. Different masu salmon subspecies (O. masou masou and $O$. masou subsp.) were introduced in the 1880 s. The current thinking is that the masu salmon in Lake Chuzenji are an admixture of two subspecies or a hybrid between two subspecies and are often referred to as "Honmasu" (Munakata et al. 1999). Detailed descriptions of Lake Chuzenji and its fish fauna are provided in Yamamoto et al. (2010) and Yokoyama and Yamamoto (2012). 


\subsection{Muscle Radiocesium Concentrations in Salmonid Fish}

Mature female masu salmon, kokanee, brown trout, and lake trout were collected from Lake Chuzenji using angling gear and gill nets from October to December 2012. Masu salmon and kokanee that were migrating upstream for spawning during September-October 2012 were collected from a weir located in a Lake Chuzenji inlet stream that passes through Fisheries Research Agency (FRA) property. Streamdwelling $S$. trutta were also collected using electrofishing equipment from the Toyama Stream, a main Lake Chuzenji inlet stream (Fig. 18.2).

Mean radiocesium concentrations $\left({ }^{134} \mathrm{Cs}+{ }^{137} \mathrm{Cs}\right)$ in muscle of masu salmon, kokanee, brown trout, and lake trout collected from the lake were $236.5 \pm 57.2[\mathrm{~Bq} /$ kg-wet \pm standard deviation (SD), $n=13], 149.9 \pm 19.6(n=13), 249.2 \pm 39.6(n=10)$, and $146.9 \pm 52.2(n=7)$, respectively (Fig. 18.3). The relationship between fork length and radiocesium concentration was not statistically significant for any of the four species $(r=0.24-0.59, P<0.05)$. Mean muscle radiocesium concentration $( \pm$ $\mathrm{SD})$ in brown trout samples collected from the inlet stream was $36.7 \pm 15.6 \mathrm{~Bq} / \mathrm{kg}$ wet $(n=10)$. The difference in radiocesium concentration between lake- and streamdwelling brown trout was statistically significant $(F=248.93$, d.f. $=1,18, P<0.001)$. A significant difference in muscle radiocesium concentration was observed among the four species collected from the lake $(F=16.38$, d.f. $=3,38, P<0.01)$. Masu salmon and brown trout had higher radiocesium concentrations than those of kokanee and lake trout (Bonferroni multiple comparisons).

Mean muscle radiocesium concentrations in the four species measured during the study period were $142.9-249.2 \mathrm{~Bq} / \mathrm{kg}$. Muscle radiocesium concentrations were also greater than $100 \mathrm{~Bq} / \mathrm{kg}$ in co-distributed species [rainbow trout, freshwater goby, Rhinogobius sp., and smelt (whole body) Hypomesus nipponensis; Fisheries Agency 2012; Fisheries Research Agency 2012]. The Ministry of Health, Labor, and Welfare, Japan placed restrictions on shipping fish with more than $100 \mathrm{~Bq} / \mathrm{kg}$ radiocesium. All salmonid fishing activities, except for catch-and-release, were prohibited in Lake Chuzenji as of June 2014.

Muscle radiocesium concentrations differed among species and between habitats within species. Lake Chuzenji masu salmon and brown trout had higher radiocesium concentrations than those of kokanee and lake trout. Lake-dwelling brown trout had much higher concentrations than those of inlet stream-dwelling brown trout. These differences may be related to differences in species-specific food intake or food availability or both. Radiocesium accumulation in freshwater fish organs results mainly from food intake (Hewett and Jefferies 1976; Forseth et al. 1991; Ugedal et al. 1995; Yamamoto et al. 2014a). Lake Chuzenji kokanee consume mostly zooplankton or chironomid larvae, whereas masu salmon, brown trout, and lake trout are omnivorous (Japan Fisheries Resource Conservation Association 2003, 2008). Higher radiocesium concentrations were found in benthic fish from Lake Chuzenji during September-November 2012 compared with zooplankton species (Fisheries Research Agency 2012). A case study of a Norwegian lake conducted after the Chernobyl reactor accident showed that brown trout feeding mostly on zoobenthos had higher radiocesium concentrations compared with those 


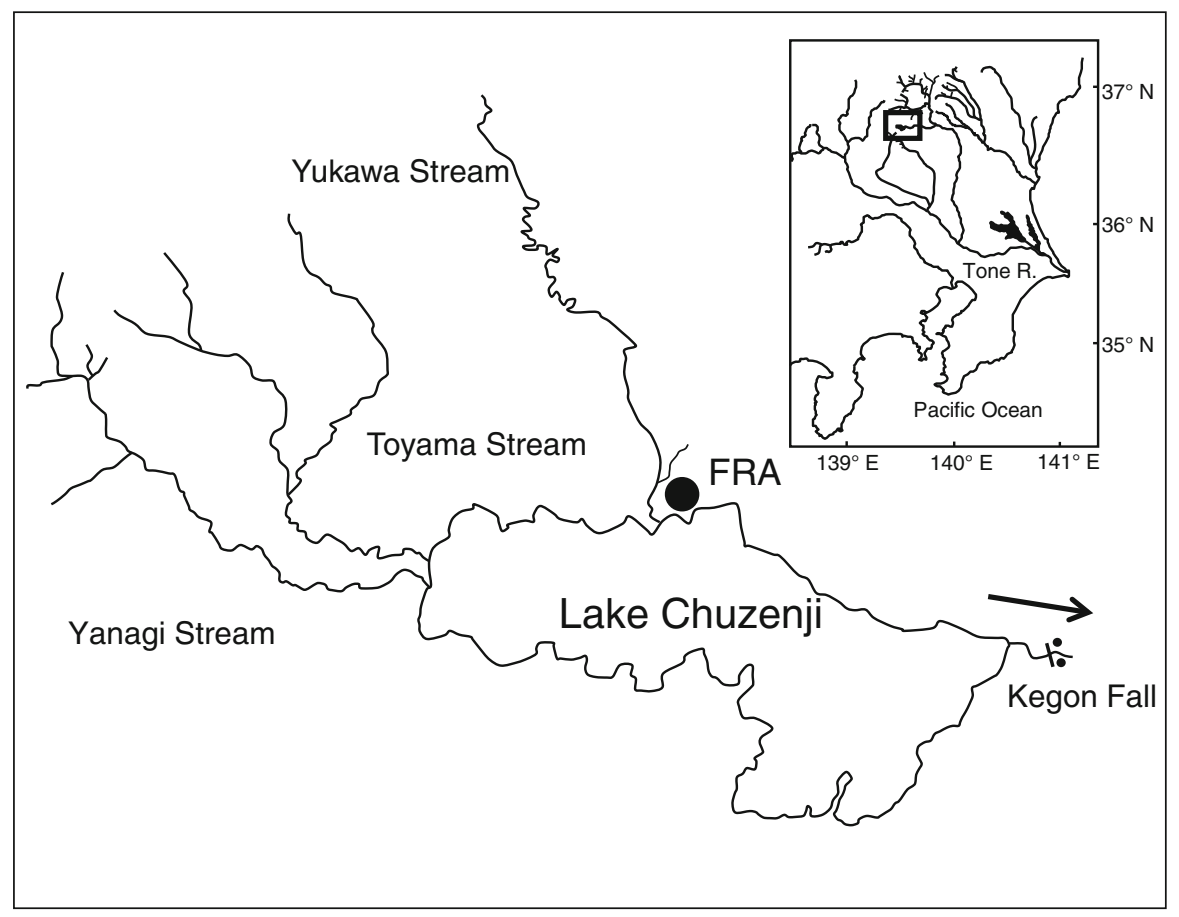

Fig. 18.2 Location of the Lake Chuzenji system, where the study was conducted
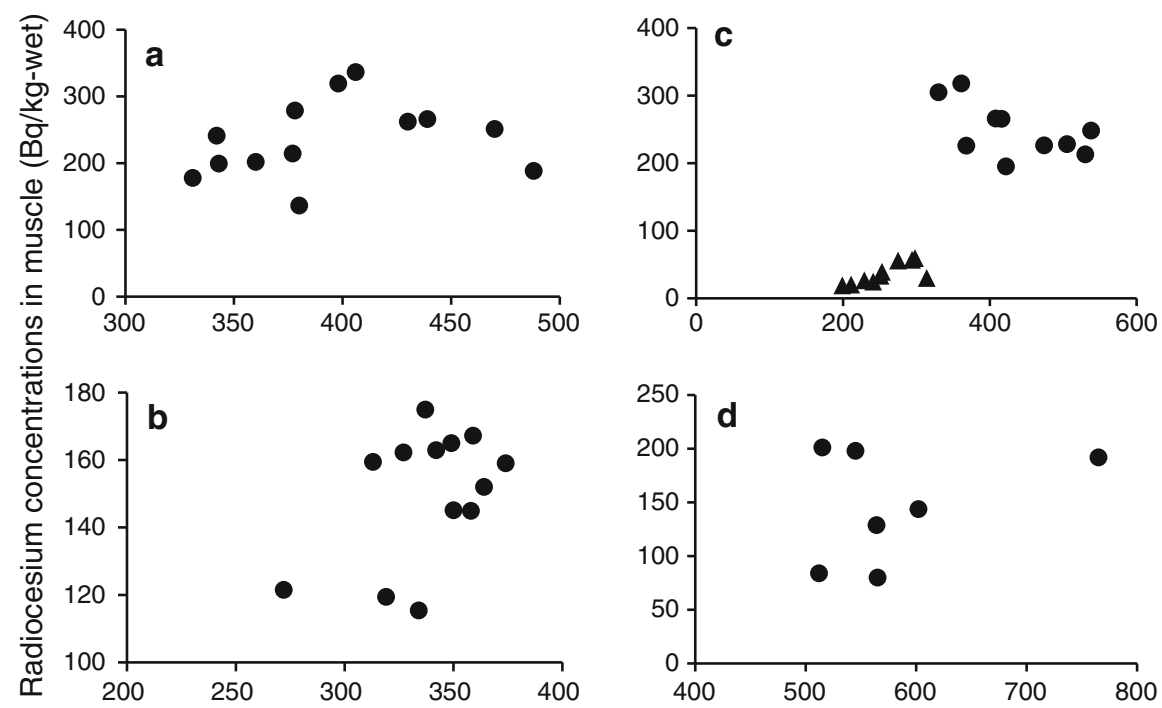

Fork Length (mm)

Fig. 18.3 Relationships between fork length and radiocesium concentrations in muscle of masu salmon (a), kokanee (b), brown trout (c), and lake trout (d) collected in Lake Chuzenji, Japan, from September to November 2012. Solid triangles indicate brown trout collected from the Lake Chuzenji inlet stream 
of sympatric Arctic charr (Salvelinus alpinus), which are planktonic feeders (Forseth et al. 1991). Segregated habitats with different dominant prey species could also cause differences in radiocesium accumulation in freshwater fish; Lake Chuzenji brown trout mainly prey on benthic gobies and smelt (Japan Fisheries Resource Conservation Association 2003), whereas inlet stream-dwelling brown trout feed on aquatic and terrestrial insects.

Radiocesium concentrations varied individually in the four salmonid species, regardless of body size. The variation was more pronounced in omnivorous masu salmon, brown trout, and lake trout than that in the planktonic kokanee. Radiocesium concentrations also varied within salmonid food items. For example, in OctoberNovember 2012, Lake Chuzenji Ephyra sp. shrimp contained 128-132 Bq/kg $\left.{ }^{134} \mathrm{Cs}+{ }^{137} \mathrm{Cs}\right)$, Palaemon sp. shrimp contained $47-94 \mathrm{~Bq} / \mathrm{kg}$, the freshwater sculpin Cottus reinii contained 166-211 Bq/kg, and freshwater goby contained $86-145 \mathrm{~Bq} / \mathrm{kg}$ (Yamamoto and Yokoduka, unpublished data). These species are major food sources for masu salmon, brown trout, and lake trout. Size-independent individual variations in diet composition may be one of the most important factors affecting variations in radiocesium accumulation, as suggested by Ugedal et al. (1995), who examined Arctic charr and brown trout in a Norwegian lake.

Mean radiocesium concentration in lake trout, which prey mainly on small fish and aquatic insects, was lower than that in masu salmon and lake-dwelling brown trout. Therefore, diet composition does not completely explain the observed radiocesium accumulation patterns. Differences in metabolic rates could also partially explain differences between fish species. Metabolic rate, which is dependent on water temperature, could affect radionuclide intake, retention, and excretion rates (Elliott et al. 1992; Ugedal et al. 1992) and thus predicts ecological half-life (Doi et al. 2012). We did not collect data on the metabolic rates of lake trout or the other co-distributed salmonids in Lake Chuzenji. However, lake trout are larger at maturity than other species, which would affect metabolic rate, food intake, and radiocesium excretion rates.

\subsection{Radiocesium Concentrations in Salmonid Eggs}

Mean radiocesium concentrations $\left({ }^{134} \mathrm{Cs}+{ }^{137} \mathrm{Cs}\right)$ in masu salmon, kokanee, brown trout, and lake trout eggs were $79.0 \pm 19.1(\mathrm{~Bq} / \mathrm{kg}$-wet $\pm \mathrm{SD}, n=13), 53.8 \pm 6.9$ $(n=13), 38.7 \pm 30.7(n=20)$, and $54.5 \pm 22.5(n=7)$, respectively (Fig. 18.4). The difference was statistically significant among the four species $(F=8.07, d . f .=3,49$, $P<0.001)$. In brown trout, mean radiocesium concentration $( \pm \mathrm{SD})$ in eggs collected from Lake Chuzenji fish was $65.6 \pm 17.5 \mathrm{~Bq} / \mathrm{kg}(n=10)$. Mean radiocesium concentration in eggs collected from fish inhabiting the inlet stream was $11.9 \pm 9.2 \mathrm{~Bq} / \mathrm{kg}$ $(n=10)$. This difference was statistically significant $(F=73.86, d . f .=1,18$, $P<0.001)$. There were significant relationships in radiocesium concentration between individual muscle and egg samples from masu salmon $(r=0.80, P<0.01)$, brown trout $(r=0.96, P<0.0001)$, and lake trout $(r=0.90, P<0.01)$. Analysis of covariance, in which egg radiocesium concentration was the dependent variable and 

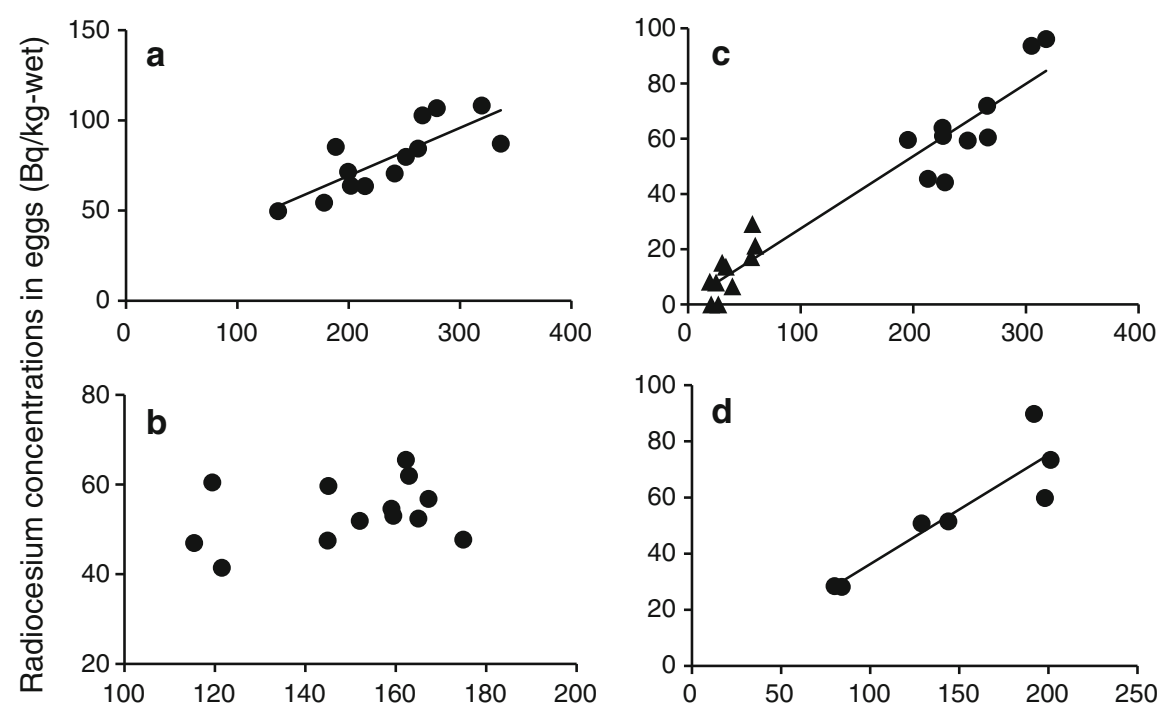

Radiocesium concentrations in muscle (Bq/kg-wet)

Fig. 18.4 Relationships between radiocesium concentrations in muscle and eggs of masu salmon (a), kokanee (b), brown trout (c), and lake trout (d) collected from Lake Chuzenji, Japan, from September to November 2012. Solid triangles indicate brown trout collected from the Lake Chuzenji inlet stream

muscle radiocesium concentration was the covariate, revealed that the cesium concentrations between individual muscle and egg was significantly different among the four species $(F=8.94$, d.f. $=3,48, P<0.001)$. For brown trout, egg radiocesium concentrations were significantly lower than the concentrations in the other three salmonid fishes (Bonferroni multiple comparisons).

The mean radiocesium concentration ratio in eggs compared with that in muscle were 0.34 for masu salmon, 0.36 for kokanee, 0.28 for brown trout, and 0.37 for lake trout. These ratios were similar to the ratios in co-distributed wild white-spotted charr (0.31) and rainbow trout (0.34; Yamamoto et al., unpublished data). Our analyses also revealed that radiocesium concentrations in masu salmon, brown trout, and lake trout eggs increased proportionally with muscle concentrations. This relationship has not been reported previously and suggests that radiocesium levels in salmonid muscle constitute a convenient surrogate for radiocesium concentrations in eggs. Salmonid eggs are important for hatchery production programs and as food. Release of hatchery-reared fish into many Japanese lakes and rivers, including the Lake Chuzenji system, contribute to immediate resource enhancement and supplement wild fisheries, which are essential components of successful freshwater fisheries management programs (Kitada 2001). Although current radiocesium levels in individual eggs were low, radiocesium turnover studies for each fish species, including elimination rate estimates, and biological and ecological half-lives at each life history stage would be indispensable to further investigate this issue. 
Acknowledgments This chapter was revised from a paper published by Yamamoto et al. (2014b). The authors are grateful to Kouji Mutou and the Lake Chuzenji Fishermen's Cooperative for collecting the fish samples and to Masato Murakami, Tomoko Okazaki, Yumiko Watanuki, and Maki Yoshida for their assistance with the sample assays and data analyses. We also thank Hiroyasu Hasegawa, Takami Morita, Kaoru Nakata, Kazuo Uchida, and Hitoshi Kubota for their critical reviews of the manuscript. This study was supported by the Fisheries Agency, Ministry of Agriculture, Forestry, and Fisheries, Japan.

Open Access This chapter is distributed under the terms of the Creative Commons Attribution Noncommercial License, which permits any noncommercial use, distribution, and reproduction in any medium, provided the original author(s) and source are credited.

\section{References}

Brittain JE, Gjerseth JE (2010) Long-term trends and variation in ${ }^{137} \mathrm{Cs}$ activity concentrations in brown trout (Salmo trutta) from Øvre Heimdalsvatn, a Norwegian subalpine lake. Hydrobiologia 642:107-113

Buesseler KO (2012) Fishing for answers off Fukushima. Science 338:480-482

Doi H, Takahara T, Tanaka K (2012) Tropic position and metabolic rate predict the long-term decay process of radioactive cesium in fish: a meta-analysis. PLoS One 7:e29295

Elliott JM, Hilton J, Rigg E, Tullette PA, Swift DJ, Leonard DRP (1992) Sources of variation in post-Chernobyl radiocesium in fish from two Cumbrian lakes (northwest England). J Appl Ecol 29:108-119

Fisheries Agency (2012) Results of the inspection on radioactivity materials in fisheries products. http://www.jfa.maff.go.jp/j/housyanou/kekka.html (in Japanese)

Fisheries Research Agency (2012) The scientific reports of nuclear accident investigations by the Fisheries Research Agency. http://www.fra.affrc.go.jp/eq/Nuclear_accident_effects/index.html (in Japanese)

Forseth T, Ugedal O, Jonsson B, Langeland A, Njåstad O (1991) Radiocesium turnover in Arctic charr (Salvelinus alpinus) and brown trout (Salmo trutta) in a Norwegian lake. J Appl Ecol 28:1053-1067

Hewett CJ, Jefferies DF (1976) The accumulation of radioactive cesium from water by the brown trout (Salmo trutta) and its comparison with plaice and rays. J Fish Biol 9:479-489

Japan Fisheries Resource Conservation Association (2003) Kosho-Kankyou no Kibanjyouhouseibi-jigyou Houkokusho. Japan Fisheries Resource Conservation Association, Tokyo (in Japanese)

Japan Fisheries Resource Conservation Association (2008). Kosho-Kankyou no Kibanjyouhouseibi-jigyou Houkokusho. Japan Fisheries Resource Conservation Association, Tokyo (in Japanese)

Jonsson B, Forseth T, Ugedal O (1999) Chernobyl radioactivity persists in fish. Nature (Lond) 400:417

Kitada S (2001) Fish stock enhancement assessment with Japan examples. Kyoritsu, Tokyo (in Japanese)

Munakata A, Amano M, Ikuta K, Kitamura S, Aida K (1999) Growth of wild honmasu salmon parr in a tributary of Lake Chuzenji. Fish Sci 65:965-966

Rask M, Saxén R, Ruuhijärvi J, Arvola L, Järvinen M, Koskelainen U, Outola I, Vuorinen PJ (2012) Short- and long-term patterns of ${ }^{137} \mathrm{Cs}$ in fish and other aquatic organisms of small forest lakes in southern Finland since the Chernobyl accident. J Environ Radioact 103:41-47

Smith JT, Comans RNJ (1996) Modelling the diffusive transport and remobilization of ${ }^{137} \mathrm{Cs}$ in sediments: the effects of sorption kinetics and reversibility. Geochim Cosmochim Acta 60:995-1004 
Tateda Y, Tsumune D, Tsubono T (2013) Simulation of radioactive cesium transfer in the southern Fukushima coastal biota using a dynamic food chain transfer model. J Environ Radioact 124:1-12

Tochigi Prefecture, Japan (2012) Tochigi Prefecture water quality chronology [fiscal year] 2012. Available from http://www.pref.tochigi.lg.jp/d03/eco/kankyou/hozen/suisitunenpyou24.html (in Japanese)

Ugedal O, Jonsson B, Njåstad O, Næumanñ R (1992) Effects of temperature and body size on radiocesium retention in brown trout, Salmo trutta. Freshw Biol 28:165-171

Ugedal O, Forseth T, Jonsson B, Njåstad O (1995) Sources of variation in radiocesium levels between individual fish from a Chernobyl contaminated Norwegian lake. J Appl Ecol 32:352-361

Yamamoto S, Kitano S, Sakano H, Yagyu M (2010) Differences in longitudinal distribution patterns along a Honshu stream of brown trout Salmo trutta, white-spotted charr Salvelinus leucomaenis, and masu salmon Onchorhynchus masou. Fish Sci 76:275-280

Yamamoto S, Mutou K, Nakamura H, Uchida K, Takagi K, Fujimoto K, Kaeriyama H, Ono T (2014a) Assessment of radiocaesium accumulation by hatchery-reared salmonids after the Fukushima nuclear accident. Can J Fish Aquat Sci 71:1772-1775

Yamamoto S, Yokoduka T, Fujimoto K, Takagi K, Ono T (2014b) Radiocaesium concentrations in the muscle and eggs of salmonids from Lake Chuzenji, Japan, after the Fukushima fallout. J Fish Biol 84:1607-1613

Yokoyama R, Yamamoto S (2012) Freshwater sculpin dwelling in Lake Chuzenji, Nikko, Kanto District, Japan, is identified as Utsusemikajika, Cottus reinii, unintentionally introduced from Lake Biwa. Ichthyol Res 59:389-393 